\title{
Effect of inoculum type and inoculation dose on ectomycorrhizal development, root necrosis and growth of Douglas fir seedlings inoculated with Laccaria laccata in a nursery
}

\author{
F. MORTIER, F. LE TACON, J. GARBAYE \\ INRA, Station de Recherches du Sol, \\ Microbiologie et Nutrition des Arbres forestiers, Centre de Recherches de Nancy, \\ Champenoux, F 54280 Seichamps
}

\begin{abstract}
Résumé
Effet de la dose et de la formulation de l'inoculum sur l'infection ectomycorhizienne, l'état sanitaire et la croissance de semis de Douglas inoculés par Laccaria laccata en pépinière
\end{abstract}

\begin{abstract}
Des semis de Douglas (Pseudotsuga menziesii) ont été cultivés en pépinière sur un sol sablolimoneux désinfecté au bromure de méthyle. L'inoculation par le champignon ectomycorhizien Laccaria laccata a été réalisée à l'aide de mycélium ayant poussé dans un mélange de vermiculite et de tourbe ou de mycélium produit en milieu liquide et inclus dans un gel d'alginate de calcium, avec trois doses différentes. Pendant toute la saison de végétation, des observations ont porté sur la croissance des semis, l'infection ectomycorhizienne et le développement des nécroses racinaires dues à Fusarium oxysporum. En fin d'année, les meilieurs résultats (par comparaison avec un témoin non inoculé) ont été obtenus avec l'inoculum inclus dans l'alginate à la dose de $5 \mathrm{~g}$ de mycélium (poids de matière sèche par $\mathrm{m}^{2}$ ), qui procure une infection presque totale par $L$. laccata, ramène l'intensité des nécroses racinaires à un niveau tolérable, et double la biomasse des semis. L'analyse de l'évolution de l'infection au cours de la saison de végétation montre que la supériorité de l'inoculum alginate est essentiellement due à une meilleure survie du champignon et à une infection plus étalée dans le temps que dans le cas de l'inoculum classique vermiculite/ tourbe. Ces résultats sont d'un grand intérêt pratique, car on sait par ailleurs que $L$. laccata, dans ce type de pépinière, permet de produire des plants plus sains et de taille commerciale en 2 ans au lieu de 3 ans, et qu'il assure une meilleure reprise et une meilleure croissance initiale après transplantation en forêt.
\end{abstract}

Mots clés : Ectomycorhizes, inoculum, alginate, Pseudotsuga menziesii, Laccaria laccata.

\section{Summary}

A fumigated nursery bed on a sandy loam was inoculated with the ectomycorrhizal fungus Laccaria laccata and seeded with Douglas fir. Two types of inoculum were compared : mycelium grown in a vermiculite/peat mixture, and mycelium grown in liquid medium and entrapped in a calcium alginate gel with different quantities of mycelium. At the end of the first growing season, the alginate inoculum at the dose of $5 \mathrm{~g}$ mycelium (dry weight) per $\mathrm{m}^{2}$ proved to be the most efficient. The top dry weight of the seedlings in this treatment was 2.3 fold that of the noninoculated fumigated controls. This inoculation treatment also ensured nearly total mycorrhizal infection by $L$. laccata and reduced root necrosis caused by fungal pathogens.

Key words : Ectomycorrhizas, inoculum, alginate, Pseudotsuga menziesii, Laccaria laccata. 


\section{Introduction}

The ectomycorrhizal fungus Laccaria laccata (Scop. ex Fr.) Cke. has proved to be very efficient for promoting the growth of conifer planting stocks in temperate nurseries and plantations (Molina, 1982; Molina \& Chamard, 1983 ; Thomas \& Jackson, 1983 ; Le TACON \& Bouchard, 1986). It also exhibits antagonism toward root pathogens which may be the main limiting factor in bare-root production of quality seedlings (Sinclair et al., 1982 ; Garbaye \& Perrin, 1986 ; Sampangi et al., 1985).

LE TACON \& Bouchard (1986) have shown that inoculation with Laccaria laccata after soil fumigation makes it possible to produce planting size Douglas fir stocks in two years (instead of the usual three years) with a high level of mycorrhizal development by this fungus. Moreover, $L$. laccata is competitive enough to survive outplanting and has the potential to provide growth stimulation for at least three years after transplanting, when compared to naturally occurring fungi (LE TACON et al., 1989).

LE TACON et al. (1983 and 1985) \& MAUPERIN et al. (1987) have shown with other ectomycorrhizal fungi that mycelium grown in a liquid medium and entrapped in calcium alginate gel (JuNG et al., 1981) is a very efficient inoculum for mycorrhizal development, and hence can be used as an alternative to the classical vermiculite/peat mixture (MARX \& BRYAN, 1975).

In order to improve the techniques of mycorrhizal inoculation with $L$. laccata, the experiment which is described here compares the efficiency of different doses of the two types of inoculum for promoting ectomycorrhizal development and growth of Douglas fir seedlings. Observations on treatment effects on root necrosis were also made.

\section{Material and methods}

\subsection{Soil}

A nursery bed in northeastern France (sandy loam soil, 4 p. 100 organic matter, pH $5.5\left(\mathrm{H}_{2} \mathrm{O}\right), 40 \mathrm{ppm}$ phosphorus extracted with $0.5 \mathrm{M} \mathrm{NaHCO}_{3}$ ) was fumigated with methyl bromide $\left(75 \mathrm{~g}\right.$ per $\mathrm{m}^{2}$, cold application technique, soil covered with polythene film for 4 days) 3 weeks before seeding in the spring. Non-fumigated plots were kept as controls in the same bed.

\subsection{Plant material}

Douglas fir (Pseudotsuga menziesii (Mirb.) Franco) seeds were pretreated for 3 weeks in wet peat at $4{ }^{\circ} \mathrm{C}$, seeded $\left(800\right.$ seeds per $\left.\mathrm{m}^{2}\right)$ and covered with a $5 \mathrm{~mm}$ layer of sieved ( $5 \mathrm{~mm}$ mesh) fumigated soil. 


\subsection{Fungal material}

Laccaria laccata (strain S-238 from USDA, Corvallis, Oregon) was grown on brewery wort diluted to $1 / 10$ (final sugars concentration : 18-20 g/l). Two types of inoculum were prepared :

- vermiculite/peat inoculum (adapted from MARX \& BRYAN, 1975) : a mixture of expanded vermiculite and sphagnum peat $(2: 1 ; \mathrm{v}: \mathrm{v})$ contained in glass jars was moistened to field capacity with the liquid medium, autoclaved for $20 \mathrm{mn}$ at $120^{\circ} \mathrm{C}$, inoculated with plugs from a culture of the fungus on agar medium, and incubated for 2 months at $25^{\circ} \mathrm{C}$ until the substrate was fully colonized. This inoculum was used in the nursery without any delay and with no washing or drying. Although MaRX (1984) has shown that removing residual nutrients was necessary with Pisolithus tinctorius, it was found unnecessary with other ectomycorrhizal fungi in nursery conditions similar to those of this experiment (Le TACON et al., 1983, Le TACON \& Bouchard, 1986);

- alginate inoculum: the fungus was grown for 30 days at $25^{\circ} \mathrm{C}$ in 1 liter Erlenmeyer flasks containing 0.51 liquid medium on a shaking table ( $40 \mathrm{rpm})$. The mycelial pellets were washed in tap water, homogenized in a Waring Blendor for 5-10 seconds and resuspended in distilled water containing $10 \mathrm{~g} / 1$ sodium alginate and $30 \mathrm{~g} / \mathrm{l}$ powdered sphagnum peat. This suspension was pumped through a pipe with $5 \mathrm{~mm}$ holes above a $100 \mathrm{~g} / 1 \mathrm{CaCl}_{2}$ solution, each drop forming a bead of reticulated calcium alginate gel 3 to $4 \mathrm{~mm}$ in diameter (MAUPERIN et al., 1987). The beads were cured in $\mathrm{CaCl}_{2}$ for $24 \mathrm{~h}$ at room temperature (for ensuring complete reticulation of the gel), washed in tap water in order to remove $\mathrm{NaCl}$, stored in air-tight containers at room temperature in order to prevent drying, and used in the nursery the next day. Three batches of beads were prepared with different mycelium concentrations giving $2 \mathrm{~g}, 5 \mathrm{~g}$ and $10 \mathrm{~g}$ mycelium (dry weight) per $\mathrm{m}^{2}$ in the nursery, the quantity of beads being constant.

\subsection{Inoculation}

The inoculum was broadcast and incorporated into the $10 \mathrm{~cm}$ topsoil with a hand tool immediately before seeding. Alginate beads were applied at the dose of 2 liters $(1.6 \mathrm{~kg})$ per $\mathrm{m}^{2}$, and the vermiculite/peat inoculum at the dose of 2 liters per $\mathrm{m}^{2}$. The quantity of mycelium in the latter was not known at the time of the experiment, but more recent chitin assays performed on the same type of inoculum (MorTiEr, unpublished data) and the results of WHIPPS (1987) suggest that it was between 1 and $2 \mathrm{~g} / \mathrm{liter}$ (dry weight) of the vermiculite/peat inoculum. Thus, the amount of mycelium per $\mathrm{m}^{2}$ in this treatment was comparable to the lower alginate treatments.

\subsection{Experimental design}

The following treatments were established:

NF-NI : unfumigated soil, no inoculation.

F-NI : fumigated soil, no inoculation.

F-VP : fumigated soil, vermiculite/peat inoculum.

F-Alg 2 : fumigated soil, alginate inoculum, $2 \mathrm{~g} / \mathrm{m}^{2}$ (dry weight) mycelium.

F-Alg 5 : fumigated soil, $5 \mathrm{~g} / \mathrm{m}^{2}$ (dry weight) mycelium.

FAlg 10 : hmigated sil, $10 \mathrm{~g} / \mathrm{m}^{2}$ (dry weight) mycelium. 
Each treatment was applied in four $0.5 \mathrm{~m}^{2}$ plots randomly distributed in 4 blocks in the nursery bed. The plots were separated from each other by a $50 \mathrm{~cm}$ non inoculated and non seeded zone.

\subsection{Nursery management}

The experimental bed was shaded during the first weeks, then watered and manually weeded during the growing season. As the nursery was known to be infested with root pathogens (mostly Fusarium oxysporum), a treatment with Benomyl $(0.8 \mathrm{~g} /$ $\mathrm{m}^{2}$ ) was applied after seeding in order to limit damping off. The average number of surviving seedlings was 120 per plot $\left(240\right.$ per $\left.\mathrm{m}^{2}\right)$, with no significant difference between treatments. No further application of fungicide was made because part of the experiment was to assess the efficiency of the different inoculation treatments in limiting root necrosis.

\subsection{Measurements}

The mean heights of the seedlings in each plot were measured on weeks 8,11 and 15. Four seedlings with heights equal to the mean value were lifted and the dry weights of the tops were measured. The root systems were gently washed and observed with a dissecting microscope in order to determine the p. 100 of ectomycorrhizal short roots. On week 25 (in October, at the end of the growing season), 10 seedlings per plot were harvested and weighed as above, and an additional observation was made : root necrosis (brown short roots) was estimated according to the following scale : 0 : no necrosis ; $1: 1 / 4$ of the root system showing necrosis $; 2: 1 / 2 ; 3: 3 / 4 ; 4:$ necrosis affecting the whole root system.

\subsection{Statistics}

The amount of mycorrhizal development (p. 100 transformed by $\operatorname{arc} \sin \sqrt{ }$ ) and dry weight of the tops at the end of the growing period were treated by analysis of variance with two controlled factors (blocks and treatments). The treatments were compared with I.s.d. $5 \%$.

No statistics were applied to the necrosis index, owing to the rough scaling system used and to the striking differences in the root morphology between the different treatments.

\section{Results}

\subsection{Mycorrhizal development (fig. 1)}

The seedlings grown on non fumigated soil became infected by Thelephora terrestris (Ehrh.) Fr. and other unidentified mycorrhizal fungi. By week 11, 45 p. 100 of short roots were naturally mycorrhizal. The mycorrhizal development increased to $74 \mathrm{p} .100$ on week 15, then decreased. The seedlings grown on fumigated, non inoculated soil were non mycorrhizal, except for a very low level of contamination by Thelephora 


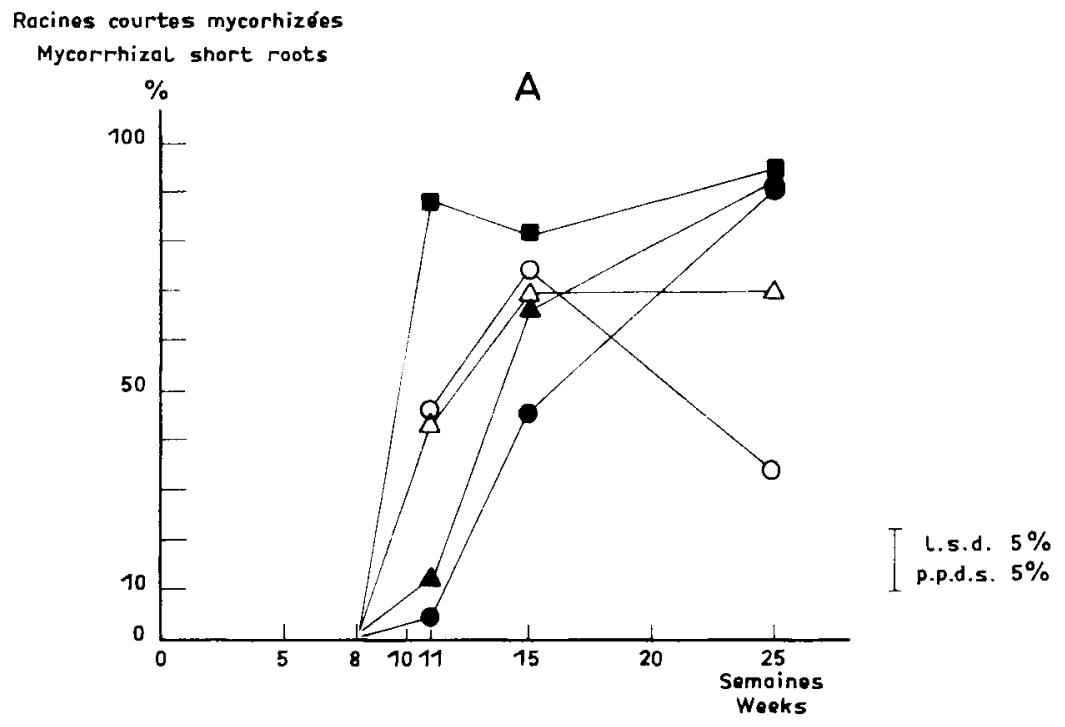

Poids sec portie oérienne

Top dry weight
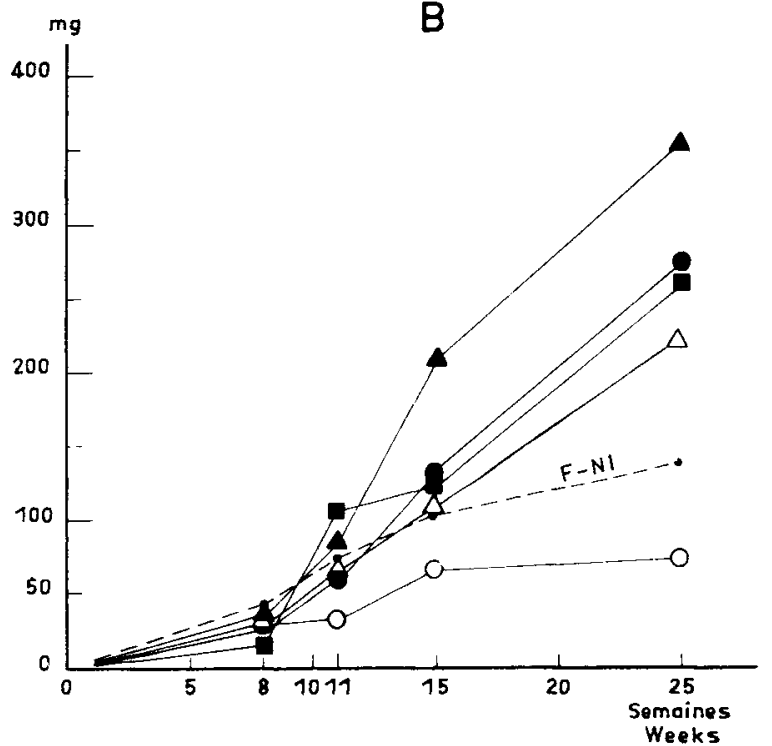

L.s.d. $5 \%$

p.p.d.s. $5 \%$

O NF-NI

- $F-A \lg 2$

$\triangle$ F-VP $\quad$ F-Alg 5

- F-ALg 10

Fig. 1

$P .100$ of ectomycorrhizal short roots $(A)$ and dry weight of the tops of the seedlings $(B)$ plotted against time. Mean values of the four replicates (blocks). The lowest significant difference

(5 p. 100 level) between treatments at the end of the growing season is shown by the vertical bar on each graph.

$P .100$ de racines courtes mycorhizées $(A)$ et poids sec de la partie aérienne d'un semis $(B)$ en fonction du temps. Moyennes des valeurs pour les quatre répétitions (blocs).

La plus petite différence significative (au risque de 5 p. 100) entre les traitements à la fin de la saison de végétation est indiquée sur chaque graphe par une barre verticale. 
terrestris (1 p. 100) on week 25. All mycorrhizas on plants inoculated with Laccaria laccata were formed by this fungus. They were clearly formed by the introduced strain of $L$. laccata, as shown by the lack of this type of mycorrhiza in the fumigated, non inoculated control. The first $L$. laccata mycorrhizas appeared between weeks 8 and 11 . Fig. 1A shows that mycorrhizal formation occurred later with Alg. 2 and Alg. 5 than with VP inoculum or Alg. 10. Mycorrhizal development with VP did not increase after week 15 (when it reached 70 p. 100), whereas it kept increasing with Alg. 2 and Alg. 5, reaching a significantly higher level at the end of the growing season (92 p. 100). In the case of Alg. 10, mycorrhizal development took place extremely quickly (from 0 to $87 \mathrm{p}$. 100 in 3 weeks) but did not increase later on. As a whole, at the end of the growing season, the three alginate inoculation treatments gave similar results, significantly better than those obtained with the vermiculite/peat inoculum.

\subsection{Growth of the seedlings (fig. 1B)}

At the end of the growing season, the seedlings in the three treatments with $L$. laccata alginate inoculum had a dry weight significantly higher than those in either fumigated or unfumigated controls. Alg. 5 plants had a significantly higher dry weight than VP ones. Except for the Alg. 10 plants which showed a spurt of growth during the fast infection period (between weeks 8 and 11), dry weight of tops increased steadily during the course of the experiment.

\subsection{Root necrosis (table 1)}

There was much root necrosis (more than half the root system affected) in both fumigated and unfumigated controls. By contrast, inoculation with $L$. laccata in association with fumigation strongly reduced root necrosis. This reduction was particularly clear in the treatments with alginate inoculum.

\section{TABLE 1}

Mean values of root necrosis rating for each treatment $(0:$ no visible necrosis $; 1: 1 / 4$ of the root system showing necrosis; $2: 1 / 2 ; 3: 3 / 4 ; 4:$ necrosis affecting the whole root system).

Valeurs moyennes des notes de nécrose racinaire dans chaque traitement 10 : pas de nécrose visible; $1: 1 / 4$ du système racinaire présentant des nécroses $; 2: 1 / 2 ; 3: 3 / 4 ;$ nécroses affectant la totalité du système racinaire).

\begin{tabular}{c|c|c|c|c|c|c}
\hline \hline Treatment & NF-NI & F-NI & F-VP & F-Alg. 2 & F-Alg. 5 & F-Alg. 10 \\
\hline Necrosis rating $\ldots \ldots \ldots \ldots \ldots$ & 2.8 & 2.8 & 1 & 0.2 & 0.4 & 0.1 \\
\hline
\end{tabular}




\section{Discussion and conclusion}

\subsection{Inoculum efficiency}

The ideal inoculum should give sufficient active propagules distributed into the soil to ensure the rapid development of many mycorrhizas. These propagules should survive long enough in order to provoke new primary mycorrhizal infection during the development of the root system (Garbaye \& Wilhelm, 1985). The vermiculite/peat inoculum fulfils the first condition, but its infectivity is limited in time : mycorrhizal development did not increase after week 15 , and $30 \mathrm{p} .100$ of the short roots were left uninfected. It is interesting to note that secondary infections did not compensate for the lack of sustained primary infections. By contrast, the alginate inoculum with approximatively the same quantity of mycelium ( 2 to $5 \mathrm{~g}$ dry weight per $\mathrm{m}^{2}$ ) resulted in a mycorrhizal development which began slowly but developed over a longer time, reaching 90 p. 100 at the end of the growing season. Thus, the mycelium entrapped in calcium alginate with powdered peat is better protected, survives longer, and has a longer lasting effect than when grown on a vermiculite-peat mixture. This result is consistent with those of MAUPERIN et al. (1987) who found that this type of inoculum was very stable during storage or after incorporation into the soil.

When the alginate inoculum was used with the highest dose of mycelium ( $10 \mathrm{~g}$ dry weight per $\mathrm{m}^{2}$ ), mycorrhizal development was very rapid, which proves that the number of fungal propagules in each bead is an important factor in the efficiency of the inoculum. This experiment does not provide any data on the effect of the number of beads in a given volume of soil on inoculum efficiency. Working with Hebeloma crustuliniforme and beech (Fagus silvatica), Garbaye \& Wilhelm (1985) have shown that the density of inoculum particles in the soil may be as important as the behaviour of the mycelium in each particle. It is probably possible to further improve the inoculation technique by optimizing the three factors together : number of beads, size of the beads and amount of living mycelium in each bead.

\subsection{Effect of Laccaria laccata on root necrosis caused by Fusarium oxysporum}

The protective effect of $L$. laccata against soil borne pathogens, and especially Fusarium oxysporum, is well documented (Sinclair et al., 1982 ; SAMPANGi et al., 1985) and was confirmed in this experiment where root necrosis was reduced from a very severe level in the non-inoculated plots to a harmless level in the presence of $L$. laccata. The indigenous mycorrhizal fungi in the nursery, including Thelephora terrestris, proved to be inefficient in this respect. Fumigation alone was inefficient too, probably because the narrow width $(1 \mathrm{~m})$ of the fumigated bed allowed rapid recolonisation by the pathogen from the adjacent soil. The same authors as cited above found that the protective effect of $L$. laccata only occurs when the mycorrhizal symbiosis is actually established. This is consistent with the fact that, in this experiment, the protection was the most effective in the treatment with the earliest mycorrhizal development. 


\subsection{Effect of Laccaria laccata on seedling growth}

The primary aim of ectomycorrhizal inoculation in forest nurseries is to produce quality seedlings free of root diseases and associated with efficient mycorrhizas, in order to ensure good survival and initial growth after outplanting. Nevertheless, growth stimulation in the nursery may be a very interesting side benefit of inoculation. In this experiment, such a benefit was clearly provided by Laccaria laccata with alginate inoculum, but it was not possible to conclude whether it was due to a direct growth stimulation by the symbiosis or to the lower impact of the root pathogens. Both hypotheses are likely to be true, according to previous results of SAMPANGi et al. (1985) in similar conditions.

\section{Acknowledgement}

The authors are gratefull to B. Dell (Murdoch University, Perth, Western Australia) for his advice when preparing the manuscript.

Reçu le 12 novembre 1987.

Accepté le 22 avril 1988.

\section{References}

Garbaye J., Perrin R., 1986. L'inoculation ectomycorhizienne des plants feuillus sur tourbe fertilisée : résultats sur chêne pédonculé (Quercus robur) avec quatre souches fongiques. Eur. J. For. Path., 16 (4), 239-246.

Garbaye J., Wilhelm M.E., 1985. Facteurs limitants et aspects dynamiques de la mycorhization contrôlée de Fagus silvatica Lin. par Hebeloma crustuliniforme (Bull. ex Saint-Amans). Quél. sur tourbe fertilisée. Ann. Sci. For., 42 (1), 53-68.

Jung G., Mugnier J., Dommergues Y., Diem H.G., 1981. Procédé d'inclusion des microorganismes du groupe des actinorhizes et des mycorhizes. Brevet $n^{\circ} 81.04474$.

Le Tacon F., Jung G., Michelot P., Mugnier J., 1983. Efficacité en pépinière forestière d'un inoculum de champignon ectomycorhizien produit en fermenteur et inclus dans une matrice de polymères. Ann. Sci. For., 40 (2), 165-176.

Le Tacon F., Jung G., Mugnier J., Michelot P., Mauperin C., 1985. Efficiency in a forest nursery of an ectomycorrhizal inoculum produced in a fermentor and entrapped in polymeric gels. Can. J. Bot., 63 (9), 1664-1666.

LE TACON F., Bouchard D., 1986. Effects of different ectomycorrhizal fungi on growth of larch, Douglas fir. Scots pine and Norway spruce seedlings in fumigated nursery soil. Oecol. Applic., 7 (4), 389-402.

Le Tacon F., Garbaye J., Bouchard D., Chevalier G., Olivier J.M., Guimberteau J., Portou N., Froснот H., 1988. Field results from ectomycorrhizal inoculation in France. Can. $J$. Bot., in press.

Mauperin Ch., Mortier F., Garbaye J., Le Tacon F., Carr G., 1987. Viability of an ectomycorrhizal inoculum produced in a liquid medium and entrapped in a calcium alginate gel. Can. $J$. Bot., 65, 2326-2329. 
MarX D., Bryan W.C., 1975. Growth and ectomycorrhizal development of Loblolly Pine seedlings in fumigated soil infested with the fungal symbiont Pisolithus tinctoritu. Forest Science, 22 (3), 245-254.

Marx D., Cordell C.E., Kenney D.S., Mexal J.G., Artman J.D., Riffle J.W., Molina R.J., 1984. Commercial vegetative inoculum of Pisolithus tinctorius and inoculation techniques for development of ectomycorrhizae on bare root tree seedlings. Forest Science monograph $\mathrm{n}^{\circ} 25$, $101 \mathrm{p}$.

Molina R., 1982. Use of the ectomycorrhizal fungus Laccaria laccata in forestry. I. Consistency between isolates in effective colonization of containerized conifer seedlings. Can. J. For. Res., 12, 469-473.

Molina R., Chamard J., 1983. Use of the ectomycorrhizal fungus Laccaria laccata in forestry. II. Effects of fertilizer forms and levels on growth of container-grown Douglas fir and ponderosa pine seedlings. Can. J. For. Res., 13, 89-95.

Sampangi R., Perrin R., Le Tacon F., 1985. Disease suppression and growth promotion of Norway spruce and Douglas fir seedlings by the ectomycorrhizal fungus Laccaria laccata in forest nurseries. In physiological and genetical aspects of mycorrhizae (proceedings of the 1st European Symposium on Mycorrhizae, Dijon, July 1985), V. et S. GianinazzI ed., INRA Paris 1986, pp. 799-806.

Sinclair W.A., Sylvia D.M., LARSEN A.O., 1982. Disease suppression and growth promotion in Douglas fir seedlings by the ectomycorrhizal fungus Laccaria laccata. For. Sci., 28 (2), 191201.

Thomas G.W., JACKSON R.M., 1983. Growth response of Sitka spruce seedlings to mycorrhizal inoculation. New Phytol., 95 (2), 223-229.

Whips J.M., 1987. Method for estimation of chitin content of mycelium of ectomycorrhizal fungi grown on solid substrates. Trans. Br. mycol. Sac., 89 (2), 199-203. 